\title{
Review on Application of Quaternary Ammonium Salts for Gas Hydrate Inhibition
}

\author{
Haizatul Hafizah Hussain and Hazlina Husin * (D) \\ Department of Petroleum Engineering, Universiti Teknologi PETRONAS, \\ Bandar Seri Iskandar 32610, Perak, Malaysia; haizatulhafizah.hus@utp.edu.my \\ * Correspondence: hazlina.husin@utp.edu.my
}

Received: 29 October 2019; Accepted: 5 December 2019; Published: 4 February 2020

check for updates

\begin{abstract}
Gas hydrate solids occurrence is considered as one of the serious challenges in flow assurance as it affects the hydrocarbon production significantly, especially in deep water gas fields. The most cost-effective method to inhibit the formation of hydrate in pipelines is by injecting a hydrate inhibitor agent. Continuous studies have led to a comprehensive understanding on the use of low dosage hydrate inhibitors such as ionic liquid and quaternary ammonium salts which are also known as dual function gas hydrate inhibitors. This paper covers the latest types of quaternary ammonium salts (2020-2016) and a summary of findings which are essential for future studies. Reviews on the effects of length of ionic liquids alkyl chain, average suppression temperatures, hydrate dissociation enthalpies, and electrical conductivity to the effectiveness of the quaternary ammonium salts as gas hydrate inhibitors are included.
\end{abstract}

Keywords: gas hydrates; hydrates inhibition; quaternary ammonium salts

\section{Introduction}

In developing deep water gas fields (about $3000 \mathrm{~m}$ water depth), the development-gathering mode of "drilling platform-underwater production submarine pipelines" is often implemented [1]. The submarine pipelines are the crucial components that provide transportation means of natural gas to flow from the reservoir wellbore to different types of deep water floating platforms such as large multi-functional semi-submersible platform (Semi-FPS), tension leg platform (TLP) [2], compliant piled tower (CPT) and deep-draft single column platform (Spar). Due to low temperatures, high static water pressure, long tieback distance, and the composition of the gas, gas hydrate solids will possibly occur in riser, subsea trees or subsea pipeline. Gas hydrates are ice-like, crystalline compounds of gas and water [3] that exist at a suitable range of high pressures and low temperatures. It consists of variety of gas molecules such as methane, ethane, propane, isobutene, n-butane, nitrogen, carbon dioxide, hydrogen sulphide, etc. [4]. Gas molecules, known as 'guest' are entrapped in the hydrogen-bonded water molecules, called 'host' [5]. Among the unique features of hydrates are; they are not chemical compounds and are non-stoichiometric crystals [6,7]. Due to no strong chemical bonds exist between the gas and water molecules [8], there is potential of the gas molecules to be released from the water molecules cage [9], which contributes to the flow assurance issues. The three most common gas hydrates structures are structure I (sI), structure II (sII), and structure H (sH), which differs in cage size and physical shape. Typically, structure I consists of small hydrate lattices that can only hold small gas molecules such as $\mathrm{CH}_{4}$. Structure II is more complex, quite larger in size, and able to entrap larger hydrocarbon molecules, whereas structure $\mathrm{H}$ is capable to contain much larger molecules such as isopentane [10]. Figure 1 shows the unit cells of sI, sII, and sH structures which are composed of different types of water cages. The conditions of gas hydrate solids occurrence is majorly governed by either its thermodynamic equilibrium or nucleation/growth rate. Chemical 
injection by adding the thermodynamic hydrate inhibitors (THIs) like methanol and mono-ethylene glycol (MEG) [5] or low-dosage hydrate inhibitors (LDHIs) such as kinetic hydrate inhibitors (KHIs) and anti-agglomerants (AAs) [11] is a common approach to either shift the equilibrium curve or delay the nucleation rate [12-17].

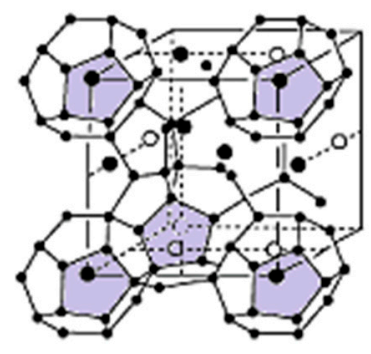

(a)

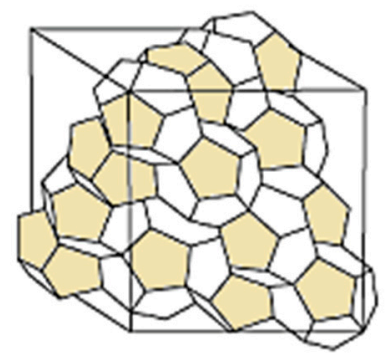

(b)

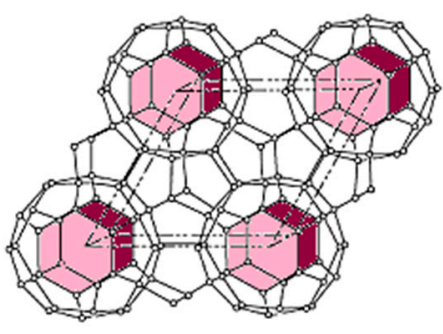

(c)

Figure 1. The three common gas hydrate structures with assembling of unit cells. (a) Structure I, (b) Structure II and (c) Structure sH.

\section{Flow Assurance Issues Related to Natural Gas}

Flow assurance is a term used to evaluate the effects of fluid hydrocarbon solids such as hydrate, wax, and asphaltene; and their potential to disrupt production due to deposition in the pipeline system $[18,19]$. Deep water environment that exists at low temperatures and high pressures provides the ideal condition for solid deposits such as hydrates to form, with the risk of reducing the hydrocarbon production. Essentially, in petroleum production operations, flow assurance activities ensure operational and economical sustainability of hydrocarbon streams from the reservoir to the surface [20]. Hydrates are often regarded as one of the most serious and challenging problems in flow assurance, since the formation rate of gas hydrates are relatively more rapid than other solid deposits, such as asphaltenes, scale and wax [21]. Hydrates which are formed inside the subsea flowlines affect the production of hydrocarbon significantly, since the formation creates blockage which seriously affect the development and production safety of deep water gas fields [22-25]. Gas-dominated wells are prone to hydrate blockage since the system cool more rapidly compared to the oil-dominated wells, which are typically insulated by design to sustain its high temperature in the flowlines prior to arrival to the surface [26]. Furthermore, when the formed hydrate completely restricts the pipelines, the pressure contained inside the pipelines will increase sharply and eventually causes a serious pipeline safety accident $[27,28]$. In order to ensure undisturbed flow of hydrocarbon transportation to the surface, up to $8 \%$ of the total estimated cost, which is equivalent to more than USD200 million is spent annually on gas hydrate inhibition techniques, as reported by [29].

\section{Gas Hydrate Inhibition}

Gas hydrates can be inhibited by either mechanical methods, i.e., pipe insulation, dehydration, and depressurization, or by chemical methods through injecting special chemicals called as hydrate inhibitors into pipelines [30]. Mechanical methods are considered impractical since they show disadvantages, such as dehydration is impossible between the well and the dehydration units, pipe insulation is too difficult and expensive to be implemented in the deep sea, and depressurization results in reduced transportation capability [31]. Thus, the most practical and economical method is by injection of hydrate inhibitor. In general, there are two major classifications of hydrate inhibitors, which are thermodynamic hydrate inhibitors (THIs) and low dosage hydrate inhibitors (LDHIs).

\subsection{Thermodynamic Hydrate Inhibitors (THIs) and Low Dosage Hydrate Inhibitors (LDHIs)}

Conventional THIs are usually based on anti-freezing solvents like methanol and mono ethylene glycol (MEG) [32], which principally works by shifting hydrate liquid vapor equilibrium (HLVE), 
however once the hydrate formation initiates, they facilitated the hydrate nucleation process and demonstrated kinetic promoters characteristics [20,33]. Meanwhile, LDHIs are generally classified into two types, kinetic hydrate inhibitors (KHIs) and anti-agglomerants (AAs). The inhibition mechanism of LDHIs differs from THIs. The inhibition by KHIs is achieved by delaying the nucleation process of the hydrate formation [34], whereas AAs allow hydrate formation however avoid agglomeration. Typically, KHIs are water-soluble polymers like polyvinyl pyrrolidone (PVP) and polyvinyl caprolactam (PVCap) [35]. Figure 2 shows a schematic diagram of kinetic hydrate inhibition mechanisms via adsorption and perturbation [36]. Adsorption inhibition shows that inhibitor molecules are adsorbed on the hydrate crystals, whereas perturbation inhibition works by disturbing the water molecules' structure. In the past decade, ionic liquids (ILs), amino acids (AACs) and quaternary ammonium salts (QAS) [37] have been introduced as green hydrate inhibitors, as well as dual function inhibitors, because they are environmentally friendly and have shown good inhibitory performance as both THIs and KHIs [38-45]. ILs are salts that are generally composed of heterocyclic cations and inorganic anions [38]. ILs have been developed as both green chemicals and designer solvents since their structure and physical properties can be fine-tuned for diverse and specific applications [10,46,47]. ILs are water-soluble, non-volatile, and less toxic than methanol, and the thermodynamic inhibition performance of some ILs is comparable to that of methanol $[19,20]$. Therefore, ILs are good substitutes to methanol as THIs.

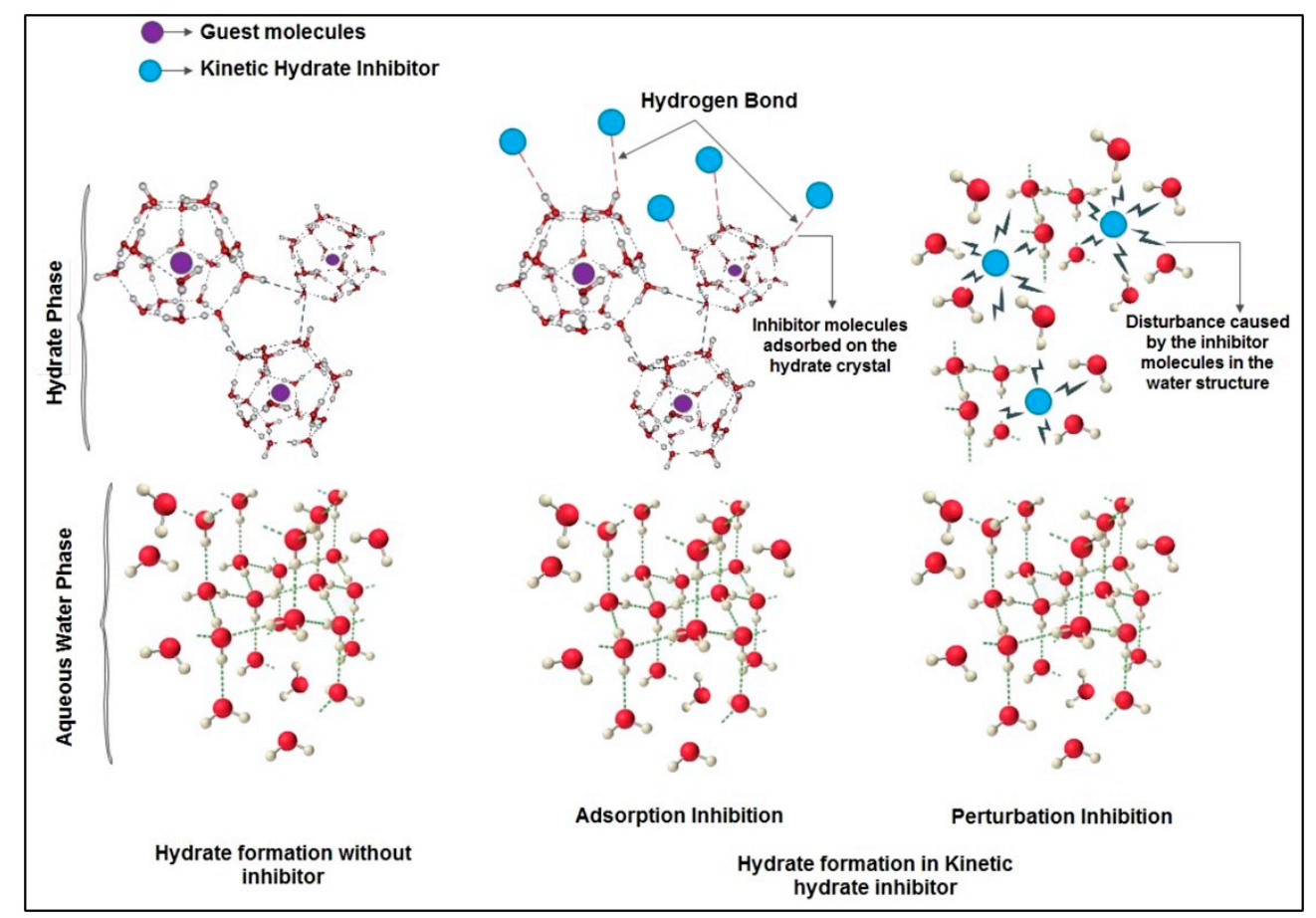

Figure 2. Schematic diagram of kinetic hydrate inhibition by adsorption and perturbation [36].

\subsection{Quaternary Ammonium Salts}

Quaternary ammonium salts (quats) (QAS) are one of the common economical IL compounds applied in industry [48]. Among their advantageous characteristics include having surface-active properties, bioactive, and possess anti-microbial activity $[49,50]$. Over the last decade, researchers have been investigating on this class of IL and found their improved chemical and thermal stability compared to imidazolium and pyridinium based ILs, their solvating properties and unique miscibility which can be utilized in specific applications [45,51-54]. A typical QAS consists of a positively-charged nitrogen atom attached to four carbon atoms [55]. Figure 3 shows a typical structure of QAS, tetramethyl ammonium chloride. 


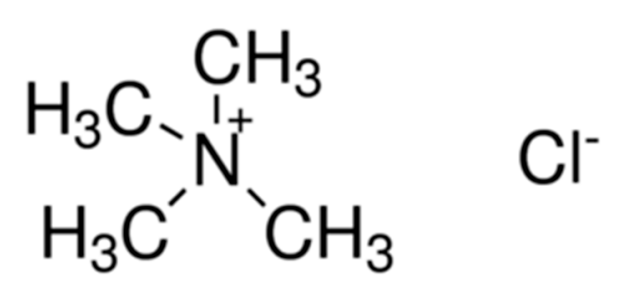

Figure 3. Molecular Structure of tetramethyl ammonium chloride.

Table 1 shows a summary of several studies conducted on QAS for gas hydrate inhibition and a brief findings on their inhibition performance. In evaluating the performance of QAS for gas hydrate inhibition, several methods has been applied, such as the T-cycle method and using highpressure micro differential scanning calorimetry equipment. The Isochoric constant cooling method or T-cycle method is one of the most used method, carried out by [37,56-62] with different type of gases to study on the kinetic inhibition of the selected compounds. In this method, $100 \mathrm{~mL}$ of liquid sample is poured into the cell which is then vacuumed thoroughly to remove excess air that may still exist in the cell $[20,63]$. The initial gas temperature is set to a temperature above the hydrate equilibrium temperature to avoid gas hydrate formation during pressurization. Then, the cell was pressurized to the specified experimental pressure. The reactor was kept for stabilization until the pressure reaches at its equilibrium with the experimental condition. The pressure and temperature measurements start getting logged when the temperature begins to decrease by rapid cooling method to facilitate the hydrate formation as it quickly rises to the desired experimental temperatures [20]. The pressure and temperature profiles are recorded for every $10 \mathrm{~s}$ through data acquisition software. 
Table 1. Summary of studies conducted on ammonium based ionic liquids for gas hydrate inhibition.

\begin{tabular}{|c|c|c|c|c|c|c|c|}
\hline Chemicals & $\begin{array}{l}\text { Chemical } \\
\text { Formula }\end{array}$ & Conc. & $\begin{array}{l}\text { Operating } \\
\text { Condition }\end{array}$ & Method \& Type of Gas & Application as & Main Findings & Year/Ref. \\
\hline $\begin{array}{c}\text { Tetraethylammonium iodide } \\
\text { (TEAI) }\end{array}$ & $\mathrm{C}_{8} \mathrm{H}_{20} \mathrm{IN}$ & \multirow{3}{*}{$\begin{array}{l}1 \mathrm{wt} \% \\
5 \mathrm{wt} \% \\
10 \mathrm{wt} \%\end{array}$} & \multirow{3}{*}{$\begin{array}{c}274-284.6 \mathrm{~K} \\
3.45-8.3 \mathrm{MPa}\end{array}$} & \multirow{3}{*}{$\begin{array}{l}\text { T-cycle method } \\
\mathrm{CH}_{4}\end{array}$} & \multirow{3}{*}{ THI } & \multirow{3}{*}{$\begin{array}{c}\text { The suppression temperature of TMAB, TEAB, and TEAI at } 10 \\
\text { wt } \% \text { is } 1.34 \mathrm{~K}, 1.07 \mathrm{~K} \text {, and } 0.82 \mathrm{~K} \text {, respectively. TMAB performed } \\
\text { better than TEAB and TEAI, individually and in combination } \\
\text { with MEG. }\end{array}$} & \multirow{3}{*}{$2020[58]$} \\
\hline $\begin{array}{l}\text { Tetramethylammonium } \\
\text { bromide (TMAB) }\end{array}$ & $\mathrm{C}_{4} \mathrm{H}_{12} \mathrm{BrN}$ & & & & & & \\
\hline $\begin{array}{l}\text { Tetraethylammonium bromide } \\
\text { (TEAB) }\end{array}$ & $\mathrm{C}_{8} \mathrm{H}_{20} \mathrm{NBr}$ & & & & & & \\
\hline $\begin{array}{l}\text { Tetramethyl ammonium } \\
\text { chloride } \\
\text { (TMACl) }\end{array}$ & $\mathrm{C}_{4} \mathrm{H}_{12} \mathrm{NCl}$ & $\begin{array}{r}1 \mathrm{wt} \% \\
5 \mathrm{wt} \% \\
10 \mathrm{wt} \%\end{array}$ & $\begin{array}{l}285.0 \mathrm{~K} \text { and } 8.00 \\
\mathrm{MPa} \text { for } \mathrm{CH}_{4} \\
283.0 \mathrm{~K} \text { and } 3.50 \\
\mathrm{MPa} \text { for } \mathrm{CO}_{2}\end{array}$ & $\begin{array}{l}\text { T-cycle method } \\
\mathrm{CO}_{2} \& \mathrm{CH}_{4}\end{array}$ & THI \& KHI & $\begin{array}{l}\text { TMACl performed efficiently as a potential dual functional } \\
\text { hydrate inhibitor for both } \mathrm{CO}_{2} \text { and } \mathrm{CH}_{4} \text { gases. The average } \\
\text { suppression temperatures for } \mathrm{TMACl} \text { at } 1,5 \text {, and } 10 \mathrm{wt} \% \text { are } 0.70 \\
\mathrm{~K}, 0.96 \mathrm{~K} \text {, and } 1.42 \mathrm{~K} \text {, respectively. }\end{array}$ & 2019 [37] \\
\hline $\begin{array}{c}\text { Tetraethyl ammonium iodide } \\
\text { (TEAI) }\end{array}$ & $\mathrm{C}_{8} \mathrm{H}_{20} \mathrm{IN}$ & \multirow{3}{*}{$\begin{array}{c}5 \mathrm{wt} \% \\
10 \mathrm{wt} \%\end{array}$} & \multirow{3}{*}{$\begin{array}{l}275.0-283.0 \mathrm{~K} \\
2.0-3.50 \mathrm{MPa}\end{array}$} & \multirow{3}{*}{$\begin{array}{l}\text { T-cycle method } \\
\mathrm{CO}_{2}\end{array}$} & \multirow{3}{*}{ THI } & \multirow{3}{*}{$\begin{array}{c}\text { The suppression temperature of TEAI, TEAB, and TMAB at } 10 \\
\mathrm{wt} \% \text { is } 1.17 \mathrm{~K}, 1.22 \mathrm{~K} \text {, and } 1.57 \mathrm{~K} \text {, respectively. TMAB performed } \\
\text { better than TEAB and TEAI individually and in mixture with } \\
\text { MEG. }\end{array}$} & \multirow{3}{*}{$2019[59]$} \\
\hline $\begin{array}{l}\text { Tetraethyl ammonium bromide } \\
\text { (TEAB) }\end{array}$ & $\mathrm{C}_{8} \mathrm{H}_{20} \mathrm{NBr}$ & & & & & & \\
\hline $\begin{array}{c}\text { Tetramethyl ammonium } \\
\text { bromide (TMAB) }\end{array}$ & $\mathrm{C}_{4} \mathrm{H}_{12} \mathrm{BrN}$ & & & & & & \\
\hline $\begin{array}{l}\text { Tetraethyl ammonium chloride } \\
\text { (TEACl) }\end{array}$ & $\mathrm{C}_{8} \mathrm{H}_{20} \mathrm{ClN}$ & $10 \mathrm{wt} \%$ & $\begin{array}{c}272.65-298.15 \mathrm{~K} \\
4.1-7.1 \mathrm{MPa}\end{array}$ & $\begin{array}{l}\text { Isochoric pressure } \\
\text { search } \\
\mathrm{CH}_{4}\end{array}$ & THI \& KHI & $\begin{array}{l}\text { TEACl enhances methane hydrate storage capacity and reduce } \\
\text { methane hydrate stability. }\end{array}$ & 2019 [60] \\
\hline $\begin{array}{l}\text { Tetraethylammonium chloride } \\
\text { (TEACl) }\end{array}$ & $\mathrm{C}_{8} \mathrm{H}_{20} \mathrm{ClN}$ & $\begin{array}{l}4.77 \mathrm{wt} \% \\
9.15 \mathrm{wt} \% \\
11.82 \\
\mathrm{wt} \%\end{array}$ & $\begin{array}{l}274.6-283.4 \mathrm{~K} \\
3.18-7.93 \mathrm{MPa}\end{array}$ & $\begin{array}{l}\text { Isochoric pressure } \\
\text { search } \\
\mathrm{CH}_{4}\end{array}$ & THI & $\begin{array}{l}\text { Addition of } 11.82 \mathrm{wt} \% \mathrm{TEACl} \text { and } 11.82 \mathrm{wt} \% \text { of } \mathrm{BMIM}^{\mathrm{B}} \mathrm{BF}_{4} \\
\text { mixture results in more reduction in methane hydrate } \\
\text { equilibrium temperature (average temperature depression of } 2.7 \\
\mathrm{~K}) \text {, compared to the other two studied mixtures. The inhibition } \\
\text { effect is also enhanced when the system pressure is increased. }\end{array}$ & 2019 [57] \\
\hline $\begin{array}{l}\text { Tetramethyl ammonium } \\
\text { bromide (TMAB) }\end{array}$ & $\mathrm{C}_{4} \mathrm{H}_{12} \mathrm{BrN}$ & \multirow{3}{*}{$\begin{array}{l}0.05 \text { and } \\
0.1 \text { mass } \\
\text { fraction }\end{array}$} & \multirow{3}{*}{$\begin{array}{l}282.4-276.8 \mathrm{~K} \\
4.2-7.6 \mathrm{MPa}\end{array}$} & \multirow{3}{*}{$\begin{array}{l}\text { Isochoric pressure } \\
\text { search } \\
\mathrm{CH}_{4}\end{array}$} & \multirow{3}{*}{ THI } & \multirow{3}{*}{$\begin{array}{l}\text { TMAB and TEAB show hydrate formation inhibition effects } \\
\text { thermodynamically. } \\
\text { However, TBAB has shown methane hydrate promotion effect. }\end{array}$} & \multirow{3}{*}{$2018[56]$} \\
\hline $\begin{array}{l}\text { Tetraethyl ammonium bromide } \\
\text { (TEAB) }\end{array}$ & $\mathrm{C}_{8} \mathrm{H}_{20} \mathrm{NBr}$ & & & & & & \\
\hline $\begin{array}{l}\text { Tetrabutyl ammonium bromide } \\
\text { (TBAB) }\end{array}$ & $\mathrm{C}_{16} \mathrm{H}_{36} \mathrm{BrN}$ & & & & & & \\
\hline $\begin{array}{l}\text { Tetraethylammonium iodide } \\
\text { (TEAI) }\end{array}$ & $\mathrm{C}_{8} \mathrm{H}_{20} \mathrm{IN}$ & $\begin{array}{l}0.1 \text { mass } \\
\text { fraction }\end{array}$ & 5.1-11.1 MPa & $\begin{array}{l}\text { HighPressure Micro } \\
\text { DSC } \\
\mathrm{CH}_{4}\end{array}$ & THI & $\begin{array}{l}\text { The presence of TEAI alters the HLVE boundary to a higher } \\
\text { pressure and lower temperature. }\end{array}$ & 2018 [64] \\
\hline $\begin{array}{l}\text { Tetra-n-butylammonium } \\
\text { bromide (TBAB) }\end{array}$ & $\mathrm{C}_{16} \mathrm{H}_{36} \mathrm{BrN}$ & $\begin{array}{c}\begin{array}{l}15,000 \\
\mathrm{ppm}\end{array} \\
\end{array}$ & \multirow[t]{2}{*}{$-0.5^{\circ} \mathrm{C}$} & \multirow{2}{*}{$\begin{array}{l}\text { Isothermal test and } \\
\text { maximum subcooling } \\
\text { test } \\
\text { THF }\end{array}$} & \multirow[t]{2}{*}{ THI \& KHI } & \multirow{2}{*}{$\begin{array}{l}\text { Crystal growth inhibition is the dominant inhibition mechanism } \\
\text { in the gas hydrate system operating in these mixtures. Although } \\
\text { THAB demonstrated poor inhibition effect with PVCap in the } \\
\text { THF hydrate tests, it shows synergy with the gas hydrate system. }\end{array}$} & \multirow[t]{2}{*}{2017 [65] } \\
\hline $\begin{array}{l}\text { Tetra-n-butylphosphonium } \\
\text { bromide (TBPB) }\end{array}$ & $\mathrm{C}_{16} \mathrm{H}_{36} \mathrm{P} \cdot \mathrm{Br}$ & $4500 \mathrm{ppm}$ & & & & & \\
\hline
\end{tabular}


Table 1. Cont

\begin{tabular}{|c|c|c|c|c|c|c|c|}
\hline Chemicals & $\begin{array}{l}\text { Chemical } \\
\text { Formula }\end{array}$ & Conc. & $\begin{array}{l}\text { Operating } \\
\text { Condition }\end{array}$ & Method \& Type of Gas & Application as & Main Findings & Year/Ref. \\
\hline $\begin{array}{l}\text { Tetramethyl ammonium } \\
\text { bromide (TMAB) }\end{array}$ & $\mathrm{C}_{4} \mathrm{H}_{12} \mathrm{BrN}$ & $10 \mathrm{wt} \%$ & \multirow{4}{*}{$\begin{array}{l}278.94-291.85 \mathrm{~K} \\
4.79-14.32 \mathrm{MPa}\end{array}$} & \multirow{4}{*}{$\begin{array}{l}\text { Isochoric pressure } \\
\text { search } \\
\mathrm{CH}_{4}\end{array}$} & \multirow{4}{*}{ THI } & \multirow{4}{*}{$\begin{array}{l}\text { TMAB, TEAB, or TPrAB slightly alters the phase equilibrium } \\
\text { conditions to a lower temperature and higher pressure region, } \\
\text { which is comparable to NaCl. In contrast, the addition of TBAB } \\
\text { and TPeAB promotes hydrate formation. }\end{array}$} & \multirow{4}{*}{2016 [61] } \\
\hline $\begin{array}{c}\text { Tetraethyl ammonium bromide } \\
\text { (TEAB) }\end{array}$ & $\mathrm{C}_{8} \mathrm{H}_{20} \mathrm{NBr}$ & $10 \mathrm{wt} \%$ & & & & & \\
\hline $\begin{array}{l}\text { Tetrapropyl ammonium } \\
\text { bromide (TPrAB) }\end{array}$ & $\mathrm{C}_{12} \mathrm{H}_{28} \mathrm{BrN}$ & $10 \mathrm{wt} \%$ & & & & & \\
\hline $\begin{array}{c}\text { Tetrabutyl ammonium bromide } \\
\text { (TBAB) }\end{array}$ & $\mathrm{C}_{16} \mathrm{H}_{36} \mathrm{BrN}$ & $\begin{array}{l}10 \mathrm{wt} \% \\
5 \mathrm{wt} \%\end{array}$ & & & & & \\
\hline $\begin{array}{l}\text { Tetramethylammonium } \\
\text { bromide (TMAB) }\end{array}$ & $\mathrm{C}_{4} \mathrm{H}_{12} \mathrm{BrN}$ & $\begin{array}{c}0.62 \\
\mathrm{~mol} \%\end{array}$ & \multirow{5}{*}{$\begin{array}{l}279.41-291.85 \mathrm{~K} \\
4.79-14.32 \mathrm{MPa}\end{array}$} & \multirow{5}{*}{$\begin{array}{l}\text { Step-heating pressure } \\
\text { search method } \\
\mathrm{CH}_{4}\end{array}$} & \multirow{5}{*}{ THI \& KHI } & \multirow{5}{*}{$\begin{array}{l}\text { TBAB or TPeAB shows semiclathrate hydrate promotion effect. } \\
\text { TMAB, TEAB or TPrAB shows slight inhibition effect. }\end{array}$} & \multirow{5}{*}{2016 [62] } \\
\hline $\begin{array}{c}\text { Tetraethylammonium bromide } \\
\text { (TEAB) }\end{array}$ & $\mathrm{C}_{8} \mathrm{H}_{20} \mathrm{NBr}$ & $\begin{array}{c}0.62 \\
\mathrm{~mol} \% \\
\end{array}$ & & & & & \\
\hline $\begin{array}{l}\text { Tetrapropylammonium } \\
\text { bromide (TPrAB) }\end{array}$ & $\mathrm{C}_{12} \mathrm{H}_{28} \mathrm{BrN}$ & $\begin{array}{c}0.62 \\
\mathrm{~mol} \%\end{array}$ & & & & & \\
\hline $\begin{array}{c}\text { Tetrabutylammonium bromide } \\
\text { (TBAB) }\end{array}$ & $\mathrm{C}_{16} \mathrm{H}_{36} \mathrm{BrN}$ & $\begin{array}{c}0.62 \\
\mathrm{~mol} \%\end{array}$ & & & & & \\
\hline $\begin{array}{l}\text { Tetrapentylammonium bromide } \\
\text { (TPeAB) }\end{array}$ & $\mathrm{C}_{20} \mathrm{H}_{44} \mathrm{BrN}$ & $\begin{array}{c}0.62 \\
\mathrm{~mol} \%\end{array}$ & & & & & \\
\hline
\end{tabular}


In order to establish the effects of additional chemicals and salts on water activity, there are different types of thermodynamic models available, such as the Dickens and Quinby Hunt $[58,66]$ which is useful in determining the hydrate liquid vapor equilibrium for $\mathrm{CH}_{4}$ hydrates. This model has also been used by other researchers $[67,68]$ due to its accuracy in predicting the hydrate phases stability boundaries [69] in the presence of IL solutions and amino acids. In evaluating the performance of a thermodynamic hydrate inhibitor, the average suppression temperature, $\Delta \mathrm{T}$ is one of the key indicator [70]. The suppression temperature $(\Delta \mathrm{T})$ is calculated by the following formula (1) [20].

$$
T=\frac{\Delta \mathrm{T}}{n}=\frac{\sum_{i=1}^{n}\left(T_{0, p i}-T_{1, p i}\right)}{n}
$$

where $T_{0, p i}$ is the temperature at equilibrium conditions for gas in a blank sample which does not contain any compound. The equilibrium temperature of gas containing inhibitor is represented by $T_{1, p i}$. In both cases, the dissociation temperatures must be determined at the same pressure values. Symbol ' $n$ ' denotes the number of points for pressure considered in the experimentation. [58]. In researches conducted by $[58,59]$ using different types of gases, they demonstrate that as the molecular weight of the IL reduces, the average suppression temperature, $\Delta \mathrm{T}$ increases. The average suppression temperature when inhibitor is tested with $\mathrm{CO}_{2}$ gas is better compared to $\mathrm{CH}_{4}$ gas since it gives a slightly higher value, as shown in Figure 4.

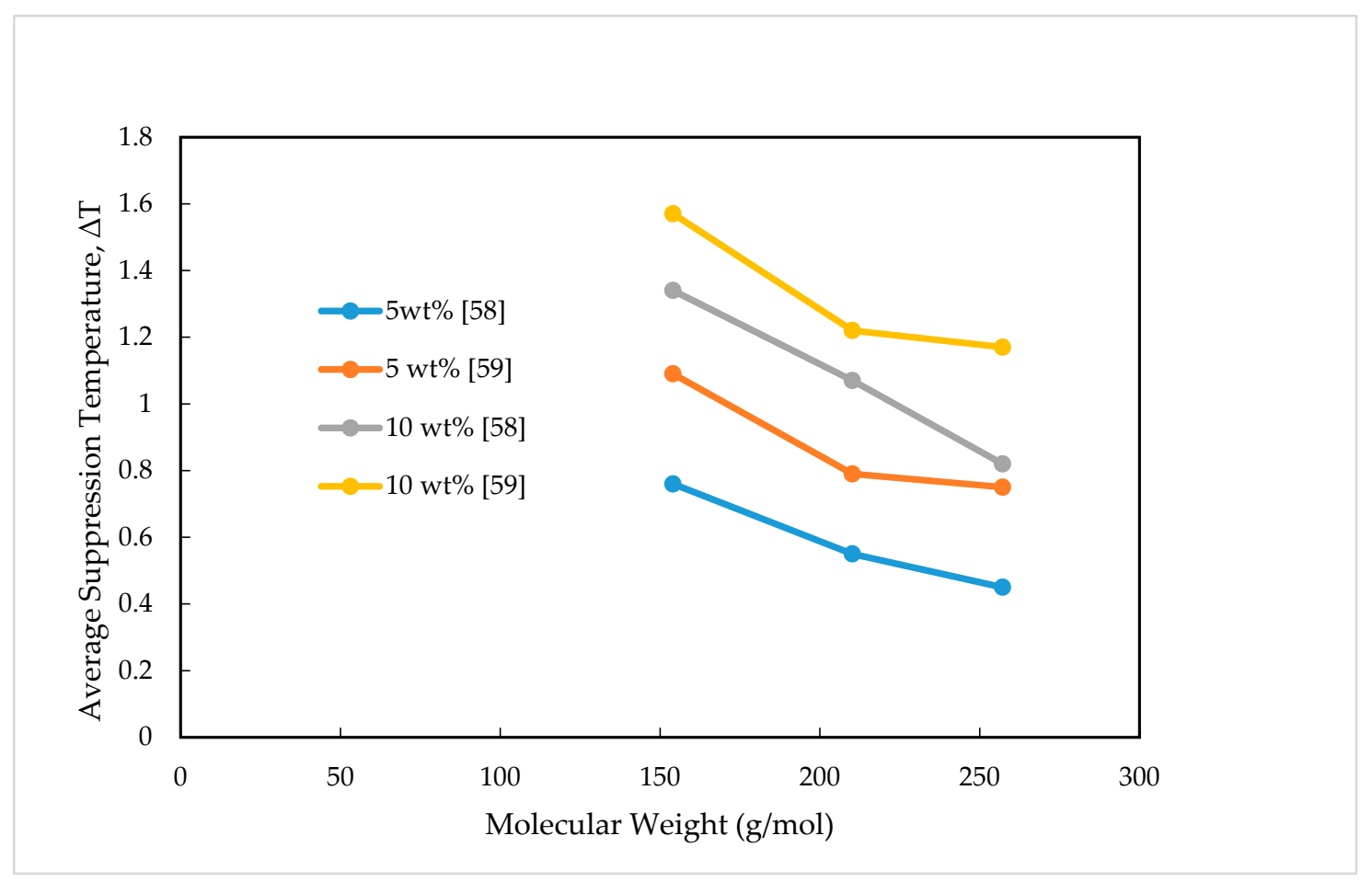

Figure 4. Average Suppression Temperature at $5 \mathrm{wt} \%$ and $10 \mathrm{wt} \%$ for Different Molecular Weight of AmmoniumBased ILs.

It has been suggested that anions of ILs play a leading role in inhibiting gas hydrates thermodynamically, while cations can also contribute to gas hydrate inhibition when specific functional groups, like a hydroxyl group (-OH), are added to them, or their chain length is modified, thus making them able to interact with water molecules $[29,31,38,71]$. Furthermore, the thermodynamic gas hydrate inhibition efficiency for ILs with the same anion attached to shorter alkyl chain $\left(\mathrm{C}_{2}\right)$ substituent is better than that of ILs with longer alkyl chain $\left(C_{4}\right)$ substituent $[10,72]$. This indicates that the length of alkyl chain [73] is one of the factors that contributes to the performance of hydrate inhibitor. Larger alkyl chain carries hydrophobicity and prohibits cations in ILs to have a bond with the hydroxyl 
ion [58]. In studying the effect of IL cations, the efficiency of ILs as THIs reduced with increasing chain length of the cation [43,74]. This is further evidenced by a study conducted by [20] using several ammonium based ILs at $10 \mathrm{wt} \%$ by maintaining the same anion, where it shows a similar trend of increasing average suppression temperature as the molecular weight decreases. It is also observed that the concentration of ILs is directly proportional to the average suppression temperature, as shown in research done by [37]. Inhibition performance is also enhanced when higher concentrations of ILs are used.

$\Delta H_{\text {diss }}$ is referred to the gas hydrate dissociation enthalpy. Dissociation enthalpies is calculated by employing Clausius-Clapeyron equation. For this purpose, derivative of the experimental HLVE data is obtained. Dissociation enthalpy is calculated by finding slope of hydrate liquid vapor equilibrium data using the Clausius-Clapeyron equation as the following formula (2) [58].

$$
\frac{\mathrm{d} \ln P}{d \frac{1}{T}}=\frac{\Delta H_{\text {diss }}}{z R}
$$

where in $T$ is the equilibrium temperature and $P$ is the pressure at which equilibrium temperature is inspected. Universal gas constant is presented as $R$ and $z$ is the compressibility factor of the gas used [58]. Hydrate dissociation enthalpy, $\Delta H_{\text {diss }}$ is dependent upon two main factors which are, the ability of clathrate structure to form hydrogen bond and cage occupancy of gas molecules [75]. Since the dissociation enthalpy values do not significantly change, it can be concluded that the chemical compounds used as inhibitor did not contribute significantly in the hydrate crystallization phase [58].

Other than average suppression temperature and hydrate dissociation enthalpy, the performance of hydrate inhibitor is also evaluated on its electrical conductivity. Recently, Ref. [56] have studied on the effects of tetrabutyl ammonium bromide (TBAB), tetraethyl ammonium bromide (TEAB), and tetramethyl ammonium bromide (TMAB), [56] on inhibiting $\mathrm{CH}_{4}$ gas hydrate formation by isochoric pressure search method. The experiment was conducted at temperature range of $282.4-276.8 \mathrm{~K}$ and pressure range of 4.2-7.6 MPa by varying concentrations, i.e., 0.05 and 0.10 mass fraction. It is observed that the addition of TMAB and TEAB shifts the phase equilibrium curve of $\mathrm{CH}_{4}$ gas hydrate to lower temperature and higher pressure regions, whereas the addition of TBAB demonstrates characteristic of hydrate formation effect. Electrical conductivity experiments results indicate that the shorter alkyl chain length of the ammonium ILs yield to higher electrical conductivity, and the sequence of electrical conductivity is TMAB $>$ TEAB $>$ TBAB [56]. The electrical conductivity is also found to be directly proportional to the concentration. In general, ILs with higher electrical conductivity show higher thermodynamic hydrate inhibition effects $[43,56]$.

Recently, Fatemeh et al. [57] have studied on the effects of QAS and IL, BMIM-BF 4 on the thermodynamic stability via experiment (isochoric pressure-search method) and modeling. The van der Waals-Platteeuw (vdWP) theory is the main reference in calculating the chemical potential of water in hydrate phase [76]. On the other hand, the Peng-Robinson (PR) equation of state [77,78] is referred to calculate the fugacity in the gas phase. The NRTL activity coefficient model $[79,80]$ is also used to investigate the water activity in the aqueous phase. It was found that the inhibition performance of methane hydrate is enhanced when both QAS and IL is combined, in which, it shows average temperature depression value of $2.7 \mathrm{~K}$, when compared to its individual performances, with $0.8 \mathrm{~K}$ and

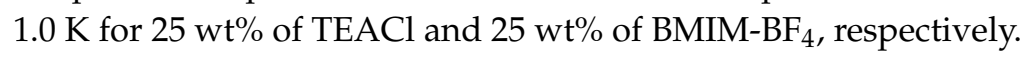

\section{Conclusions}

This paper covers on different types of QAS for gas hydrate inhibition for different type of gases at variety of operating conditions, concentrations, and by using different methods. It also gives a correlation of length of alkyl chain, average suppression temperatures, hydrate dissociation enthalpies, and electrical conductivity [81] to the effectiveness of the QAS as gas hydrate inhibitors. The QAS exhibited hydrate inhibition characteristics that are similar to the traditional thermodynamic hydrate inhibitors such as methanol and glycol [9], in which they shift the hydrate liquid vapor equilibrium 
curve to a lower temperature and higher pressure. It is recommended that future research works to be conducted in investigating the synergy effects of QAS with other compounds, via chemical bonding interactions, such as amino acids, fatty acids and other types of polymers.

Author Contributions: Conceptualization, H.H.H. and H.H.; Resources, H.H.H. and H.H.; Writing-Original Draft Preparation, H.H.H.; Writing-Review and Editing, H.H.H. and H.H. All authors have read and agreed to the published version of the manuscript.

Funding: This research work conducted by the first author was funded by YUTP-FRG grant (015LC0-064).

Acknowledgments: The authors would like to acknowledge and thank the Department of Petroleum Engineering UTP and YUTP-FRG grant (015LC0-064) in supporting this research.

Conflicts of Interest: The authors declare no conflict of interest.

\section{References}

1. Liu, W.; Li, X.; Hu, J.; Wu, K.; Sun, F.; Sun, Z.; Chu, H.; Qi, X. Research on flow assurance of deepwater submarine natural gas pipelines: Hydrate prediction and prevention. J. Loss Prev. Process Ind. 2019, 61, 130-146. [CrossRef]

2. Fang, H.; Duan, M. Chapter 4-Special problems of deep-sea oil and gas engineering. Offshore Oper. Facil. 2014, 537-686. [CrossRef]

3. Hong, S.Y.; Lim, J.I.; Kim, J.H.; Lee, J.D. Kinetic studies on methane hydrate formation in the presence of kinetic inhibitor via in situ Raman spectroscopy. Energy Fuels 2012, 26, 7045-7050. [CrossRef]

4. Abbasi, A.; Hashim, F.M. A review on the Application of Empirical Models to Hydrate Formation Prediction. MATEC Web Conf. 2014, 13, 02035. [CrossRef]

5. Ke, W.; Svartaas, T.M.; Chen, D. A review of gas hydrate nucleation theories and growth models. J. Nat. Gas Sci. Eng. 2019, 61, 169-196. [CrossRef]

6. Glew, D.N. Some Stoicheiometric Gas Hydrates. Nature 1959, 184, 545-546. [CrossRef]

7. Davidson, D. The motion of guest molecules in clathrate hydrates. Can. J. Chem. 1971, 49, 1224-1242. [CrossRef]

8. Krishna, L.; Koh, C.A. Inorganic and methane clathrates: Versatility of guest-host compounds for energy harvesting. MRS Energy Sustain. 2015, 2, E8. [CrossRef]

9. Ke, W.; Kelland, M.A. Kinetic hydrate inhibitor studies for gas hydrate systems: A review of experimental equipment and test methods. Energy Fuels 2016, 30, 10015-10028. [CrossRef]

10. Tariq, M.; Rooney, D.; Othman, E.; Aparicio, S.; Atilhan, M.; Khraisheh, M. Gas Hydrate Inhibition: A Review of the Role of Ionic Liquids. Ind. Eng. Chem. Res. 2014, 53, 17855-17868. [CrossRef]

11. De Menezes, D.É.S.; Filho, P.D.P.; Fuentes, M.D.R. Use of 1-Butyl-3-methylimidazolium-based ionic liquids as methane hydrate inhibitors at high pressure conditions. Chem. Eng. Sci. 2019, 115323. [CrossRef]

12. Lederhos, J.; Long, J.; Sum, A.; Christiansen, R.; Sloan, E., Jr. Effective kinetic inhibitors for natural gas hydrates. Chem. Eng. Sci. 1996, 51, 1221-1229. [CrossRef]

13. Del Villano, L.; Kommedal, R.; Kelland, M.A. Class of kinetic hydrate inhibitors with good biodegradability. Energy Fuels 2008, 22, 3143-3149. [CrossRef]

14. Kelland, M.A. History of the Development of Low Dosage Hydrate Inhibitors. Energy Fuels 2006, 20, 825-847. [CrossRef]

15. Sum, A.K.; Sandler, S.I. Ab initio calculations of cooperativity effects on clusters of methanol, ethanol, 1-propanol, and methanethiol. J. Phys. Chem. A 2000, 104, 1121-1129. [CrossRef]

16. Masoudi, R.; Tohidi, B.; Anderson, R.; Burgass, R.W.; Yang, J. Experimental measurement and thermodynamic modelling of clathrate hydrate equilibria and salt solubility in aqueous ethylene glycol and electrolyte solutions. Fluid Phase Equilib. 2004, 219, 157-163. [CrossRef]

17. Cha, M.; Shin, K.; Kim, J.; Chang, D.; Seo, Y.; Lee, H.; Kang, S.-P. Thermodynamic and kinetic hydrate inhibition performance of aqueous ethylene glycol solutions for natural gas. Chem. Eng. Sci. 2013, 99, 184-190. [CrossRef]

18. Ahmed, T. Equations of State and PVT Analysis; Gulf Publishing Company: Houston, TX, USA, 2007.

19. Mokhatab, S.; Poe, W.A. Handbook of Natural Gas Transmission and Processing; Gulf Professional Publishing: Houston, TX, USA, 2012. 
20. Khan, M.S.; Lal, B.; Shariff, A.M.; Mukhtar, H. Ammonium hydroxide ILs as dual-functional gas hydrate inhibitors for binary mixed gas (carbon dioxide and methane) hydrates. J. Mol. Liquids 2019, 274, 33-44. [CrossRef]

21. Wang, Y.; Koh, C.A.; White, J.; Patel, Z.; Zerpa, L.E. Hydrate formation management simulations with anti-agglomerants and thermodynamic inhibitors in a subsea tieback. Fuel 2019, 252, 458-468. [CrossRef]

22. Guo, Y.; Meng, X.; Meng, T.; Wang, D.; Liu, S. A novel method of risk assessment based on cloud inference for natural gas pipelines. J. Nat. Gas Sci. Eng. 2016, 30, 421-429. [CrossRef]

23. Wasden, F.K. Flow Assurance in Deepwater Flowlines and Pipelines-Challenges Met, Challenges Remaining. Presented at the Presented at the Offshore Technology Conference, Houston, TX, USA, 5-8 May 2003.

24. Yu, W.; Song, S.; Li, Y.; Min, Y.; Huang, W.; Wen, K.; Gong, J. Gas supply reliability assessment of natural gas transmission pipeline systems. Energy 2018, 162, 853-870. [CrossRef]

25. Yu, W.; Wen, K.; Min, Y.; He, L.; Huang, W.; Gong, J. A methodology to quantify the gas supply capacity of natural gas transmission pipeline system using reliability theory. Reliab. Eng. Syst. Saf. 2018, 175, $128-141$. [CrossRef]

26. Sloan, E.D. Natural Gas Hydrates in Flow Assurance; Gulf Professional Publishing: Houston, TX, USA, 2010.

27. Chaudhari, P.; Zerpa, L.E.; Sum, A.K. A correlation to quantify hydrate plugging risk in oil and gas production pipelines based on hydrate transportability parameters. J. Nat. Gas Sci. Eng. 2018, 58, 152-161. [CrossRef]

28. Trummer, S.A.; Mohallem, R.; Franco, E.; de Assis, J.V. Hydrate Remediation During Well Testing Operations in the Deepwater Campos Basin, Brazil. Presented at the Presented at the SPE/ICoTA Coiled Tubing \& Well Intervention Conference \& Exhibition, The Woodlands, TX, USA, 26-27 March 2013.

29. Sloan, E.D. Fundamental principles and applications of natural gas hydrates. Nature 2003, 426, 353. [CrossRef] [PubMed]

30. Bai, Y.; Bai, Q. Subsea Engineering Handbook; Gulf Professional Publishing: Houston, TX, USA, 2012.

31. Tang, C.; Liang, D. Inhibitory effects of novel green inhibitors on gas hydrate formation. Chin. J. Chem. Eng. 2019, 27, 2107-2117. [CrossRef]

32. Khan, M.S.; Lal, B.; Bustam, M.A. Gas Hydrate Inhibitors. In Chemical Additives for Gas Hydrates; Springer: Berlin/Heidelberg, Germany, 2020; pp. 27-46.

33. Sloan, E.D., Jr.; Koh, C.A. Clathrate Hydrates of Natural Gases; CRC Press: Boca Raton, FL, USA, 2007.

34. Ke, W.; Chen, D. A short review on natural gas hydrate, kinetic hydrate inhibitors and inhibitor synergists. Chin. J. Chem. Eng. 2019, 27, 2049-2061. [CrossRef]

35. Cha, J.-H.; Kang, S.-P.; Han, S.; Kang, J.W.; Kim, K.-S. Phase equilibria of $\mathrm{CH}_{4}$ and $\mathrm{CO}_{2}$ hydrates formed from aqueous solutions of glutaric acid and malonic acid. Fluid Phase Equilib. 2016, 413, 71-74. [CrossRef]

36. Kakati, H.; Mandal, A.; Laik, S. Synergistic effect of Polyvinylpyrrolidone (PVP) and L-tyrosine on kinetic inhibition of $\mathrm{CH}_{4}+\mathrm{C}_{2} \mathrm{H}_{4}+\mathrm{C}_{3} \mathrm{H}_{8}$ hydrate formation. J. Nat. Gas Sci. Eng. 2016, 34, 1361-1368. [CrossRef]

37. Khan, M.S.; Lal, B.; Keong, L.K.; Ahmed, I. Tetramethyl ammonium chloride as dual functional inhibitor for methane and carbon dioxide hydrates. Fuel 2019, 236, 251-263. [CrossRef]

38. Lee, D.; Go, W.; Seo, Y. Experimental and computational investigation of methane hydrate inhibition in the presence of amino acids and ionic liquids. Energy 2019, 182, 632-640. [CrossRef]

39. Sa, J.H.; Kwak, G.H.; Han, K.; Ahn, D.; Cho, S.J.; Lee, J.D.; Lee, K.H. Inhibition of methane and natural gas hydrate formation by altering the structure of water with amino acids. Sci. Rep. 2016, 6, 31582. [CrossRef] [PubMed]

40. Sa, J.-H.; Kwak, G.-H.; Lee, B.R.; Park, D.-H.; Han, K.; Lee, K.-H. Hydrophobic amino acids as a new class of kinetic inhibitors for gas hydrate formation. Sci. Rep. 2013, 3, 2428. [CrossRef] [PubMed]

41. Sa, J.-H.; Lee, B.R.; Park, D.-H.; Han, K.; Chun, H.D.; Lee, K.-H. Amino Acids as Natural Inhibitors for Hydrate Formation in CO2 Sequestration. Environ. Sci. Technol. 2011, 45, 5885-5891. [CrossRef] [PubMed]

42. Kim, K.-S.; Kang, J.W.; Kang, S.-P. Tuning ionic liquids for hydrate inhibition. Chem. Commun. 2011, 47, 6341-6343. [CrossRef]

43. Xiao, C.; Wibisono, N.; Adidharma, H. Dialkylimidazolium halide ionic liquids as dual function inhibitors for methane hydrate. Chem. Eng. Sci. 2010, 65, 3080-3087. [CrossRef]

44. Xiao, C.; Adidharma, H. Dual function inhibitors for methane hydrate. Chem. Eng. Sci. 2009, 64, $1522-1527$. [CrossRef]

45. Plechkova, N.V.; Seddon, K.R. Ionic liquids:"designer" solvents for green chemistry. Methods Reag. Green Chem. 2007, 105-130. [CrossRef] 
46. Plechkova, N.V.; Seddon, K.R. Applications of ionic liquids in the chemical industry. Chem. Soc. Rev. 2008, 37, 123-150. [CrossRef] [PubMed]

47. Marsh, K.N.; Deev, A.; Wu, A.C.; Tran, E.; Klamt, A. Room temperature ionic liquids as replacements for conventional solvents-A review. Korean J. Chem. Eng. 2002, 19, 357-362. [CrossRef]

48. Stojanovic, A.; Morgenbesser, C.; Kogelnig, D.; Krachler, R.; Keppler, B.K. Quaternary ammonium and phosphonium ionic liquids in chemical and environmental engineering. In Ionic Liquids: Theory, Properties, New Approaches; IntechOpen: London, UK, 2011.

49. Boethling, R.S.; Lynch, D.G. Quaternary ammonium surfactants. In Detergents; Springer: Berlin/Heidelberg, Germany, 1992; pp. 145-177.

50. Juergensen, L.; Busnarda, J.; Caux, P.Y.; Kent, R.A. Fate, behavior, and aquatic toxicity of the fungicide DDAC in the Canadian environment. Environ. Toxicol. 2000, 15, 174-200. [CrossRef]

51. Wasserscheid, P.; Welton, T. Ionic Liquids in Synthesis; John Wiley \& Sons: Hoboken, NJ, USA, 2008.

52. Chowdhury, S.; Mohan, R.S.; Scott, J.L. Reactivity of ionic liquids. Tetrahedron 2007, 63, 2363-2389. [CrossRef]

53. Rogers, R.D.; Seddon, K.R.; Volkov, S. Green Industrial Applications of Ionic Liquids; Springer Science \& Business Media: Berlin/Heidelberg, Germany, 2012.

54. Leyma, R.; Platzer, S.; Jirsa, F.; Kandioller, W.; Krachler, R.; Keppler, B.K. Novel thiosalicylate-based ionic liquids for heavy metal extractions. J. Hazard. Mater. 2016, 314, 164-171. [CrossRef] [PubMed]

55. Khan, M.S.; Lal, B.; Bavoh, C.B.; Keong, L.K.; Bustam, A.; Mellon, N.B. Influence of Ammonium based Compounds for Gas Hydrate Mitigation: A Short Review. Indian J. Sci. Technol. 2017, 10, 1-6. [CrossRef]

56. Gupta, P.; Nair, V.C.; Sangwai, J.S. Phase Equilibrium of Methane Hydrate in the Presence of Aqueous Solutions of Quaternary Ammonium Salts. J. Chem. Eng. Data 2018, 63, 2410-2419. [CrossRef]

57. Kazemi, F.; Javanmardi, J.; Aftab, S.; Mohammadi, A.H. Experimental study and thermodynamic modeling of the stability conditions of methane clathrate hydrate in the presence of TEACl and/or BMIM-BF4 in aqueous solution. J. Chem. Thermodyn. 2019, 130, 95-103. [CrossRef]

58. Qasim, A.; Khan, M.S.; Lal, B.; Ismail, M.C.; Rostani, K. Quaternary ammonium salts as thermodynamic hydrate inhibitors in the presence and absence of monoethylene glycol for methane hydrates. Fuel 2020, 259, 116219. [CrossRef]

59. Qasim, A.; Khan, M.S.; Lal, B.; Shariff, A.M. Phase equilibrium measurement and modeling approach to quaternary ammonium salts with and without monoethylene glycol for carbon dioxide hydrates. J. Mol. Liquids 2019, 282, 106-114. [CrossRef]

60. Rasoolzadeh, A.; Javanmardi, J.; Mohammadi, A.H. An experimental study of the synergistic effects of BMIM-BF4, BMIM-DCA and TEACl aqueous solutions on methane hydrate formation. Pet. Sci. 2019, 16, 409-416. [CrossRef]

61. Su, Y.; Bernardi, S.; Searles, D.J.; Wang, L. Effect of Carbon Chain Length of Organic Salts on the Thermodynamic Stability of Methane Hydrate. J. Chem. Eng. Data 2016, 61, 1952-1960. [CrossRef]

62. Su, Y.; Bernardi, S.; Searles, D.J.; Wang, L. Phase equilibria and gas storage capacity of clathrate hydrates of methane+ quaternary ammonium salts. In Proceedings of the Chemeca 2016: Chemical Engineering-Regeneration, Recovery and Reinvention, Adelaide, Australia, 25-28 September 2016; p. 418.

63. Peng, B.-Z.; Chen, J.; Sun, C.-Y.; Dandekar, A.; Guo, S.-H.; Liu, B.; Mu, L.; Yang, L.-Y.; Li, W.-Z.; Chen, G.-J. Flow characteristics and morphology of hydrate slurry formed from (natural gas+ diesel oil/condensate oil+ water) system containing anti-agglomerant. Chem. Eng. Sci. 2012, 84, 333-344. [CrossRef]

64. Nashed, O.; Dadebayev, D.; Khan, M.S.; Bavoh, C.B.; Lal, B.; Shariff, A.M. Experimental and modelling studies on thermodynamic methane hydrate inhibition in the presence of ionic liquids. J. Mol. Liquids 2018, 249, 886-891. [CrossRef]

65. Kelland, M.A.; Hartanti, A.R.D.; Ruysschaert, W.G.Z.; Thorsen, H.B. Tetrahydrofuran Hydrate Crystal Growth Inhibition with Synergistic Mixtures: Insight into Gas Hydrate Inhibition Mechanisms. Energy Fuels 2017, 31, 8109-8115. [CrossRef]

66. Dickens, G.R.; Quinby-Hunt, M.S. Methane hydrate stability in pore water: A simple theoretical approach for geophysical applications. J. Geophys. Res. Solid Earth 1997, 102, 773-783. [CrossRef] 
67. Bavoh, C.B.; Nashed, O.; Khan, M.S.; Partoon, B.; Lal, B.; Sharif, A.M. The impact of amino acids on methane hydrate phase boundary and formation kinetics. J. Chem. Thermodyn. 2018, 117, 48-53. [CrossRef]

68. Partoon, B.; Wong, N.M.S.; Sabil, K.M.; Nasrifar, K.; Ahmad, M.R. A study on thermodynamics effect of [EMIM]-Cl and [OH-C2MIM]-Cl on methane hydrate equilibrium line. Fluid Phase Equilib. 2013, 337, $26-31$. [CrossRef]

69. Bavoh, C.B.; Partoon, B.; Lal, B.; Gonfa, G.; Khor, S.F.; Sharif, A.M. Inhibition effect of amino acids on carbon dioxide hydrate. Chem. Eng. Sci. 2017, 171, 331-339. [CrossRef]

70. Khan, M.S.; Bavoh, C.B.; Partoon, B.; Nashed, O.; Lal, B.; Mellon, N.B. Impacts of ammonium based ionic liquids alkyl chain on thermodynamic hydrate inhibition for carbon dioxide rich binary gas. J. Mol. Liquids 2018, 261, 283-290. [CrossRef]

71. Bai, Y.; Bai, Q. Subsea Engineering Handbook; Gulf Professional Publishing: Amsterdam, The Netherlands, 2018.

72. Peng, X.; Hu, Y.; Liu, Y.; Jin, C.; Lin, H. Separation of ionic liquids from dilute aqueous solutions using the method based on $\mathrm{CO}_{2}$ hydrates. J. Nat. Gas Chem. 2010, 19, 81-85. [CrossRef]

73. Cha, J.-H.; Kim, K.-S.; Lee, H. Size-selective Pd nanoparticles stabilized by dialkylmorpholinium ionic liquids. Korean J. Chem. Eng. 2009, 26, 760-764. [CrossRef]

74. Li, X.-S.; Liu, Y.-J.; Zeng, Z.-Y.; Chen, Z.-Y.; Li, G.; Wu, H.-J. Equilibrium hydrate formation conditions for the mixtures of methane+ ionic liquids+ water. J. Chem. Eng. Data 2010, 56, 119-123. [CrossRef]

75. Koh, C.A.; Sloan, E.D.; Sum, A.K.; Wu, D.T. Fundamentals and Applications of Gas Hydrates. Annu. Rev. Chem. Biomol. Eng. 2011, 2, 237-257. [CrossRef] [PubMed]

76. Holder, G.D.; Mokka, L.P.; Warzinski, R.P. Formation of gas hydrates from single-phase aqueous solutions. Chem. Eng. Sci. 2001, 56, 6897-6903. [CrossRef]

77. Peng, D.-Y.; Robinson, D.B. A New Two-Constant Equation of State. Ind. Eng. Chem. Fundam. 1976, 15, 59-64. [CrossRef]

78. Shen, X.-D.; Zhou, X.-B.; Liang, D.-Q. Kinetic Effects of Ionic Liquids on Methane Hydrate. Energy Fuels 2019, 33, 1422-1432. [CrossRef]

79. Renon, H.; Prausnitz, J.M. Liquid-Liquid and Vapor-Liquid Equilibria for Binary and Ternary Systems with Dibutyl Ketone, Dimethyl Sulfoxide, n-Hexane, and 1-Hexene. Ind. Eng. Chem. Fundam. Process Des. Dev. 1968, 7, 220-225. [CrossRef]

80. Renon, H.; Prausnitz, J.M. Local compositions in thermodynamic excess functions for liquid mixtures. AIChE J. 1968, 14, 135-144. [CrossRef]

81. Sabil, K.M.; Nashed, O.; Lal, B.; Ismail, L.; Japper-Jaafar, A. Experimental investigation on the dissociation conditions of methane hydrate in the presence of imidazolium-based ionic liquids. J. Chem. Thermodyn. 2015, 84, 7-13. [CrossRef]

(C) 2020 by the authors. Licensee MDPI, Basel, Switzerland. This article is an open access article distributed under the terms and conditions of the Creative Commons Attribution (CC BY) license (http://creativecommons.org/licenses/by/4.0/). 